\title{
Societies of Disindividuated Hyper-Control: On the Question of a New Pharmakon
}

\section{Review by Ekin Erkan}

Stiegler, Bernard. The Age of Disruption: Technology and Madness in Computational Capitalism. Polity Press, 2019.

Drawing on Adorno and Horkheimer's oft-quoted 1944 essay, "The Culture Industry: Enlightenment as Mass Deception," Bernard Stiegler's The Age of Disruption affirms that the Frankfurt School duo scrupulously envisaged a "new kind of barbarism," or an inversion of modernity's Enlightenment project illustrated by our contemporary political semblance. Surveying the critical social fissures that index contemporary Western civil society - from 9/11 to the 2002 Nanterre massacre and the 2015 Charlie Hebdo shooting - Stiegler diagnoses that that our epoch is plagued by the "absence of epoch" (153), whereby the computational capitalism and algorithmic governmentality have extirpated the "transcendental imagination" underlying vital primordial narcissism. In short, these are symptoms a world increasingly "going mad," in a thousand ways, possible because we are the bearers of "a negative protention of a becoming without future," yet "we prefer not to say so: we do not want to know about it" (173).

Stiegler's work is, of course, is informed by Gilbert Simondon, Jacques Derrida, Bertrand Gille, Edmund Husserl and Martin Heidegger, alike - though it is Simondon and Husserl who comprise the most direct influences. Throughout his work, Stiegler speaks of "retentions," whereby "primary retentions" are sense perceptions, "secondary retentions" are memories, and "tertiary retentions" are media (culture mnemonics). Stiegler's notion of "retentions" and "protentions" is directly informed by Husserl's theory of time-consciousness. Instead of dividing time into tripart mold - consisting of present eventual perception, memory of a past event, and expectation of a future event - Husserl solves the problem of unity and multiplicity by integrating the structure of perception using three different functions: "retention," "primal impression," and "protention." For Husserl, the mind consists of a series of modifications of perceptual memory-images; thus, he distinguishes between the retentions of experience. A "retention" is a temporally removed experience that acts as the background of older beliefs, to which newer beliefs are then mapped. Primary memory maintains what has just been experienced (the primary impressions that register it), whereas protentions are directed towards that which will yet occur.

Insofar as Stiegler's theory of retention and protention is concerned with tools and technological artifacts (technics), Stiegler is equally steeped in Gilbert Simondon's notion of mental reality, or what Simondon termed "technical mentality." Technical mentality refers to that which is "projected onto a support that is neither cerebral nor psychical but rather technical," which Stiegler terms "mnemotechnics." In Simondon's epistemological work, technics constitute the experience of temporality as the relation between the body, technology, and environmental milieu. For Stiegler, these "retentions" precede us while, simultaneously, they are also a part of us - consequently, they comprise "pre-individual funds," as they refer to forms of retentions that were created prior to the birth of an individual, though one can access these through "cultural memory."

While Stiegler is influenced by Husserl's phenomenology of time-consciousness, as a student of Derrida, he poses the logic of the supplement to transfigure "tertiary retention," or the condition of possibility of play between Husserl's primary retention and secondary retention. Thus, tertiary retentions are generated by the "conquest of space and time through its technicization" (Hui 2016: x). Following André Leroi-Gourhan's writing on the rhythm of radio and television infiltrating and colonizing "urban time" in Gesture and Speech (196), Stiegler's conception of tertiary retentions portends the schematic conditions that facilitate a (supplemental) kind of exteriorized memory (or "third memory"). 
"Disindividuation," a term that Stiegler often returns to, refers to the closing off of the possibility of forming critical protentions (or individuation). As The Age of Disruption is directed towards our contemporary digital epoch, Stiegler charges digital tertiary retention with a disruptive capacity, as they can take control of these culturally common preindividual funds. As such, disruption radically purges the possibility of identification and idealization through the liquidation of primordial narcissism.

Stiegler's notion of primordial narcissism has Freudian roots, as it veers towards sublimation and the mediation of the ego as that "which begins by changing sexual object-libido into narcissistic libido" (1948: 199). The / is founded on this primordial narcissism, which must be maintained and protected against pathological forms - "social engineering" or "social networking" pose the possibility of undoing primordial narcissism's protective capacity and it's opportunity to "form psychic and singular protentions" (30). For Stiegler, primordial narcissism is occluded by the age of disruption, which "destroys the faculty of dreaming that...opens up the possibility of effecting (opérer) bifurcations through which anthropic Anthropos becomes neganthropic" (201). Stiegler's project conceives of reticulated (networked) digital tertiary retentions, as they are articulated and (digitally) massified, as pharmakon, pushing for a new macroeconomic framework constituting a general economy of contribution (25).

Schrödinger's "neganthropy," or "negative entropy," precludes Stiegler's portmanteau of negenthropos/the neganthropocene. A mere footnote in What is Life? (1944), for Schrödinger "neganthropos" referred to a kind of disparate "free energy," or alterity that eludes biological equilibrium. For Stiegler, we best experience Schrödinger's negenthropy when, "in a sunbeam we suddenly see...the fertility of everything that is renewed again...the ordinary experience of ressurection" (27). As tehcnics offer the possibility to transgress automatic behavior, being "noninhuman" appears as the moment of transgression, where we circumvent technics and produce a future that differs from the present's entropic tendency. Negenthropy is politicized as Stiegler provokes the Anthropocene's dismal hypothesis with the possibility of political dynamism.

As poetically alluded in this moment, Negenthropy begins with an affirmatoration, the "feeling of existing" whereby the ego becomes its own object of love. It is a way out of the data economy's exploitation of all reticulated transinidivdual relations (e.g. metadata collection). Negenthropy has a parallel relationship to primordial narcissism, as they both reinscribe noetic activity (or philia). Primordial narcissism facilitates "an intermittent critique of foundations and dogmas" (239) by rational activity of the mind as it relates of what Pascal termed libido sciendi, or "the lust of knowledge."

Libidinally counseled from / to the we, primordial narcissism allows for the process of identification. As it presupposes the ego-ideal of the parent (which, itself, orders and metastabilizes affective relations woven via transindividuation), secondary narcissism, formed through processes of collective individuation (and stemming from collective protentions), presents a double-edged condition: while it bears the possibility for positive collective protentions to come, it also always threatens to turn pathologically into its opposite (parochialism and chauvinism). The ghost of madness constantly haunts "non-inhuman beings." These protentions usher the Anthropocene to its limits, with accompanying barbarous behavior ranging from far-right extremism to jihadism. Hence, as denoetization (the "question of madness") de-realizes the real, ergo, extremisms proliferate.

As Alex Galloway and Jason Lariviere demonstrate in their work on compression (drawing form Stiegler's earlier California lectures on culture industries), technologies of capitalism, from the assembly line to Facebook, have created processes of "disindividuation," short-circuiting the productive becoming of individuation while resulting in desublimation. Thus, the infinite potential of becoming is continuously compressed into the finite gestures of capitalist proletarianization, as the grammatization of gesture is exacerbated by the exteriorization of human experiences onto digital platforms, resulting in the loss of savoir-faire ["knowledge of how to make do"] (Galloway et al. 2017:131).

For Stiegler, we occupy an epoch of reticulated and automated disruption, a "new kind of barbarism" that is induced by existential loss. Stiegler points to terrorism and sociological case studies of isolated and suicidal dividuals, such as Richard Durn and Andreas Lubitz, to proffer how the key pharmacological questions in our "epoch of disruption" involve how the technological powers that we lionize as "civilizational progress" become 
transfigured as weapons of destruction, revealing a dynamic subterranean barbarism. Disruption, constantly outstripping and overtaking social organization, renders the will "obsolete in advance," thereby destroying reason (understood as rational knowledge). Thus, "[d]isruption moves quicker than any will, whether individual or collective, from consumers to 'leaders', whether political or economic" (8).

In The Age of Disruption, Stiegler's characterization of "negative protention" is perhaps best summed by his reference to the words of a disenchanted youth - fifteen year old Florian. Florian' statement, published in L'Effondrement du temps, notes that "[w]hen I talk to young people of my generation...they all say the same thing: we no longer have the dream of starting a family, of having children, or a trade or ideals, as you yourselves did when you were teenagers. All that is over and done with, because we're sure that we will be the las generation, or one of the last" (L'impansable 2006: 7). Stiegler often returns to Florian, the young man whose dismal confrontational sentiments synecdochally index a widespread generational "correlative loss of reason," the very loss that Chris Anderson glorifies as the "end of theory."

As the destruction of primordial narcissim leads to madness (the loss of reason) it, in turn, results in the growth of despair, or the loss of "reasons for hope." For Stiegler, this amounts in the "final reckoning to the growth of madness," as the inevitable result of factors that, "when they combine, compound their potentials in a way that goes beyond every limit" (174). The conditions for such madness are manifold. They includes dismal scientific anticipations, such as Donella Meadows' 1972 Limits to Growth report, which demonstrates that the Anthropocene's metasystemic crisis could prove fatal to the biosphere. As economic insolvency has annulled public power, Big Data's penchant towards sentiment analysis invokes the destruction of affective spheres. As resentment escalates, cultural, artistic, and political transgenerational ties dissipate, fomenting violent behavior that recursively reproduces itself with an infernal spiral of chaos. One only need point to Dylann Roof in Charleston or Yassin Salhi in Saint-Quentin-Fallavier to affirm Stiegler's canvas of "psychic disindividuation" ands it collective closure with "collective disindividuation."

In the tradition of those media theorists championing interventionist or tactical media (ranging from Geert Lovink to McKenzie Wark and French anarchist collective Tiqqun), Stiegler advocates for anti-capitalist praxis, or a new hermeneutics "borne by these screens" (2018: 176). In The Age of Disruption, Stiegler produces an alternative to the current "tyranny of digital lifestyles," exalting the Elinor Ostrom and Benjamin Coriat's marcoecolocigal "culture of the commons."

This digital culture-to-come must collectively individuate, producing "new moral beings" who are "deproletarianized," or "once again capable of noetic dreaming" (295). For Stiegler, this will not occur under "technological solutionism." Thus, Stiegler diverges from Catherine Malabou's exclamatory approbration of creative non-calculation, connectionist deep-learning, and machinic plasticity (as articulated in Morphing Intelligence). Rather, for Stiegler, the "moral being" of digital culture will be that of the neganthropic practitioner who takes hold of the canonical contributory value of the commons economy. Thus is the "conversion the come," the force of the Neganthropocene, will produce a kind of miraculous noetic dream that stumps the entropic state of disruptive emergency that is "the concrete reality of the Anthropocene" (299). Emphasizing what Aristotle called $\phi ı \lambda i a$ (philia), Stiegler aspire for a society found on learning so as to deflect automatic society's immense process of unlearning, withdrawal, and disaffection.

Stiegler also warns of the return to discourses of mastery, both technical or rhetorical. Such spatial politics, which Nick Srnicek and Alex Williams laud in their 2013 accelerationist manifesto, seeks to "rehabilitate the 'mastery' abandoned by the discourse of 'postmodernity"' (290). This technofetishestic solution is inadequate, as it draws for the superficial transhumanist impulse that seeks enhancement or augmentation (296). Similarly, while Stiegler is sympathetic to the cause, he also does not conceive of crypto-Marxist hacktivism outside of its reticulated stasis within "Hayekian ultra-libertarianism" (113).

Stiegler's thesis draws considerably from Foucault's 1961 preface in The History of Madness, which was removed from the 1972 edition following Derrida's critique in "Cogito and the History of Madness" (1963). Foucault's original preface presented reason in the classical age in its relation to madness, with reason understood as a "trick that 
madness plays." This opposes much of the standard Foucauldian archeological historiography, whereby history is understood as a social enclosure progressively circumscribing madness, treating it as unreason. With Stiegler's revival, we find that history of this classical reason as a kind of madness, or as a "new form of madness." Stiegler reconceives of this "trick of madness" as that which foreshadows our current moment of transhumanist "neobarbarism."

Amending Deleuze's "control society," where individuals are rendered dividuals, or entry-points for datafication, Stiegler terms "[s]ocieties of hyper-control," transfixed as aggregations of individuals who are increasingly automatically disindividuated (disintegrated). By way of Deleuze and Sloterdijk, Stiegler fills in Foucault's shortcoming, as Foucault's Madness and Civilization occludes the historical fact of marketing "as the functional organization of innovation by disinhibition" (120). As Deleuze fundamentally links the advent of control societies to marketing and the exploitation of affects via calculability, Stiegler appropriately reshapes biopower so that it is epochally fit for the twentieth century, with probability calculation pooling and amortizing protentions. Thus, in Stiegler's model, biopower now presupposes psychopower, which is invested in the immaterial or psychological realm.

As Sloterdijk notes in In the World Interior of Capital, "Columbus was an agent of a pan-European willingness to embrace delusion - though it was psychotechnically perfected by the USA in the twentieth century (and reimported to Europe through the consultancy industry)" (2017: 57). Through Sloterdijk, Stiegler allows us to see the genesis of the psychotechnologies (e.g. games, computers, SMS, and other such factors of the culture industry) of psychopower, which seep through consumerist capitalism and deluge hyper-control society. In cognitive capitalism, the reshaped and psychotechnologized manifestation of psychopower is neuropower, which works to "produce changes in the material logics of the brain by affecting the brain's neuron and synapses" (Ash 2015: 38). Tracing Sloterdijk's undertaking of the history of disinhibition (from colonialism to neoliberal globalization), Stiegler deftly demonstrates how the "consultancy industry" along with the data economy, now constitutes a totality of the "activity culture" of modernity.

Stiegler's philosophical oeuvre has sought to not only analyze (and denounce) where necessary, but also to propose alternative pharmacological political possibilties. Thus, Stiegler's socio-political projects, ranging from his publications to educational endeavors like Ars Industrialis and legal ventures like "Internation.World," are united in their efforts of instrumentalizing "analog retentions" as pharmakon. For Stiegler, a new pharmakon arose with digital tertiary retentions, integrating analogue tertiary retention by enfolding it within the process of digitalization. This has made it possible for the humanist project to extend beyond the industrial model's functional producerconsumer dichotomy (24). Such opportunities will develop solely if they are socialized, or assisted by an industrial policy - consequently, Stiegler's newest project, "Internation.World," is an international memorandum to the United Nations, galvanized by the aim of creating an agreement between different localities to work together and experiment with macro-economic models that will address the urgent challenges of the Anthropocene.

The Age of Disruption provides an all-encompassing map of Stiegler's multifaceted oeuvre. At times, Stiegler indulges us in his fascinating anecdotes, including his time spent in prison studying philosophy under Gérard Granel's tutelage, or the role of jazz and Malcolm X in Stiegler's own psychosocial individuation. One personal favorite passage recounts a bar that Stiegler opened in Toulose, which "functioned as a nocturnal musical joint" until it was "closed down by the police shortly before my arrest" (74). Yet, Stiegler never indulges us in anecdotal musings for whimsy's sake, eruditely "annotating" himself within the reticulated political milieu at hand.

For Stiegler, our epoch is characterized by the "absence of epoch," colored by the fulfilment of nihilism in which disruption sustains the extreme demoralization described. Stiegler's project is a radicalization of the process of disinhibition described by Sloterdijk and Jean-Baptiste Fressoz in The Shock of the Anthropocene. However, by way of Derridean deconstruction, Stiegler instrumentalizes "epokhal redoubling," or the co-option and management of technologies of disadjustment. Wielded by the epistemophilic commons, tertiary protentions can be directed towards "transindividuation" rather than Big Data's "transdividuation." While Stiegler's text requires preliminary knowledge of his previous work, it also adroitly pleaches his entire ethico-political project. As we realize 
a kind of primordial self-affirmation, relishing the sun's flaxen flare, Stiegler's pharmacological critique presents us with a newfound Marxian mode to illuminate the production of a pharmakon - a neganthropic future.

\section{References}

Adorno, Theodore W. and Max Horkheimer. "The Culture Industry: Enlightenment as Mass Deception." Dialectic of Enlightenment. London: Verso, 2016.

Anderson, Chris. "The End of Theory: The Data Deluge Makes the Scientific Method Obsolete." Wired, Conde Nast, 26 Jan. 2018, www.wired.com/2008/06/pb-theory/.

Ash, James. The Interface Envelope: Gaming, Technology, Power. London: Bloomsbury Academic, 2016.

Bonneuil, Christophe, and Jean-Baptiste Fressoz. The Shock of the Anthropocene: the Earth, History, and Us. London: Verso, 2017.

Deleuze, Gilles. Negotiations 1972-1990. New York: Columbia University Press, 1995.

Freud, Sigmund, "Totem and Taboo." in Volume 13 of James Strachey (ed. and trans.), The Standard Edition of the Complete Psychological Works of Sigmund Freud. London: Hogarth Press, 1948.

Foucault, Michel. Madnes and Civilization: a History of Insanity in the Age of Reason. New York: Routledge, 1999.

Galloway, Alexander R., and Jason R. Larivière. "Compression in Philosophy." Boundary 2, vol. 44, no. 1, 2017, pp. 125-147., doi:10.1215/01903659-3725905.

L'impansable, L'Effrondrement du temps: Tome 1, Pénétration. Paris: Le Grand Souffle Editions, 2006.

Malabou, Catherine. Morphing Intelligence: from IQ Measurement to Artificial Brains. New York: Columbia University Press, 2019.

Sloterdijk, Peter, and Wieland Hoban. In the World Interior of Capital for a Philosophical Theory of Globalization. Cambridge, UK: Polity Press, 2017.

Srnicek, Nick, and Alex Williams ( 2013), "\#Accelerate : Manifesto for an Accelerationist Politics," Critical Legal Thinking, May 14. criticallegalthinking.com/2013/05/14/accelerate-manifesto-for-an-accelerationist-politics/ (accessed December 12, 2017).

Stiegler, Bernard. The Neganthropocene. Open Humanities Press, 2018.

. The Age of Disruption: Technology and Madness in Computational Capitalism. Cambridge, UK: Polity Press, 2019.

\section{Cite this Essay}

Erkan, Ekin. "Societies of Disindividuated Hyper-Control: On the Question of a New Pharmakon." Rhizomes: Cultural Studies in Emerging Knowledge, no. 35, 2019, doi:10.20415/rhiz/035.r02

RHIZOMES ISSN 1555-9998 ^ 230 East Hall Bowling Green State University Bowling Green, OH 43403

Editors: Ellen Berry and Carol Siegel. Reviews editor: Craig J. Saper. Technical editor: Helen J Burgess 